\title{
A LATE ROMAN LUXURY VILLA IN NAGYHARSÁNY, AT THE FEET OF THE SZÁRSOMLYÓ MOUNTAIN
}

\section{Zsolt Mráv ${ }^{1}$}

Hungarian Archaeology Vol. 10 (2021), Issue 1, pp. 11-21. https://doi.org/10.36338/ha.2021.1.2

Those who visit the tourist attractions of the Villány-Siklós wine route may not even suspect that a ruin of a high-status Roman villa is hiding under the picturesque landscape with vineyards at the foot of the Szársomlyo Mountain. The Mediterranean beauty and climate of this region attracted the late imperial elite of the Roman Empire, among whom an influential, senatorial family built its luxury villa here. This villa only revealed its significance and treasures slowly. After the excavation of its bathhouse, an unfortunately commissioned deep ploughing twisted large pieces of the mosaic floors out of the ground. After a long pause, the Hungarian National Museum continued the investigation of the site in 2016. The excavations brought to light the villa's banquet hall, the floor of which was once covered with colourful mosaics representing the highest quality of Roman mosaic art. Masterpieces of Roman glass craftmanship-pieces of a wine set-were also found here. The villa of Nagyharsány plays an important role in the research of the Seuso Treasure too. The luxury reflected by the interior decoration and the artefacts of the banquet hall proved that the educated and wealthy imperial aristocracy was present in late Roman Pannonian provinces, the members of which could afford a set of silver tableware comparable to the Seuso Treasure in quality, understood the literary and visual culture based on the classical education of the elite, and spoke its sophisticated language.

Keywords: Roman period, Pannonia, villa, imperial elite, Nagyharsány, mosaic, cage cup, dichroic glass

The late imperial villa estate is situated in the south of Baranya county, between Nagyharsány and Villány, at the southern foot of the scenic Szársomlyó Mountain, in the fields named Kopár and Kopáralja (Fig. 1). A Mediterranean-like microclimate characterizes the barren southern slopes of the mountain. In Hungary, this is the area with the highest average number of sunshine hours. The unique climatic circumstances provided favourable conditions for humans to settle here, which is detectable at the site from the Bronze Age.

Romans discovered the region of the Szársomlyó in the second half of the 1st century AD at the latest. They established a sparsely built-in, village-like settlement that ran $1 \mathrm{~km}$ long at the foot of the mountain. Stone buildings started to appear in the Severan

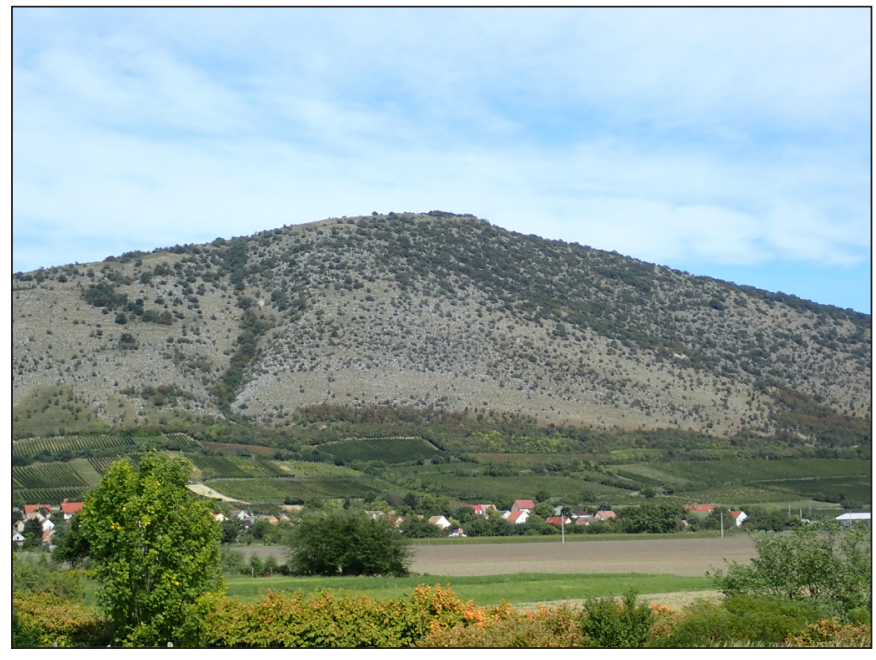

Fig. 1. The barren southern slope of the Szársomlyó Mountain (photo: Zsolt Mráv) period (AD 193-235), and they clustered in the centre of the settlement stretching over the Kopáralja area, which indicates a development towards an estate centre. The most spectacular transformation of the settlement's history took place in the second half of the 4th century, when the already existing, earlier villa was built into a luxury residence with reception and banquet halls furnished with mosaics, new dwelling and bathhouses, and garden facilities. This study aims to present this late Roman high-status villa, the real significance of which is only becoming evident for us today, in light of the restarting archaeological investigations.

1 Archaeologist, deputy head of Department for Archaeology in the Hungarian National Museum. Budapest. E-mail: mrav. zsolt@mnm.hu 


\section{MOSAIC PLOUGHING IN NAGYHARSÁNY - THE DISCOVERY AND ARCHAEOLOGICAL RESEARCH OF THE LATE ROMAN VILLA}

In the 1960s, Ferenc Fülep, general director of the Hungarian National Museum, started the excavation of the site that had long been known for its archaeological finds. His investigations revealed one of the bathhouses of the settlement (FÜLEP 1979, 312) (Fig. 2). The next chapter in the site's research history began with a scandal that created a general stir in both the domestic and international media (MRÁV 2019, 18-19). The co-operative of Villány decided to plant grapes in the neighbourhood of the former excavations in 1974. Although the "earth was cracking" right from the start of the ploughing, and the plough brought complete wall blocks and colourful mosaic fragments to the surface, the chief engineer decided to continue, even though Ferenc Fülep had already made actions at the site to stop the earthwork. The devastating result was that the middle third of the central building complex and in that, an estimated 60 square meter mosaic floor, was ploughed out (Fig. 3). Although the majority of the mosaic fragments lying on the surface were taken to the museum, we cannot even guess the number of the fragments that got lost in the meantime. Besides the irreversible and serious damage that the deep ploughing caused at the site, it also showed that the villa had richly decorated halls with mosaic floors, and therefore it deserves further investigations. In

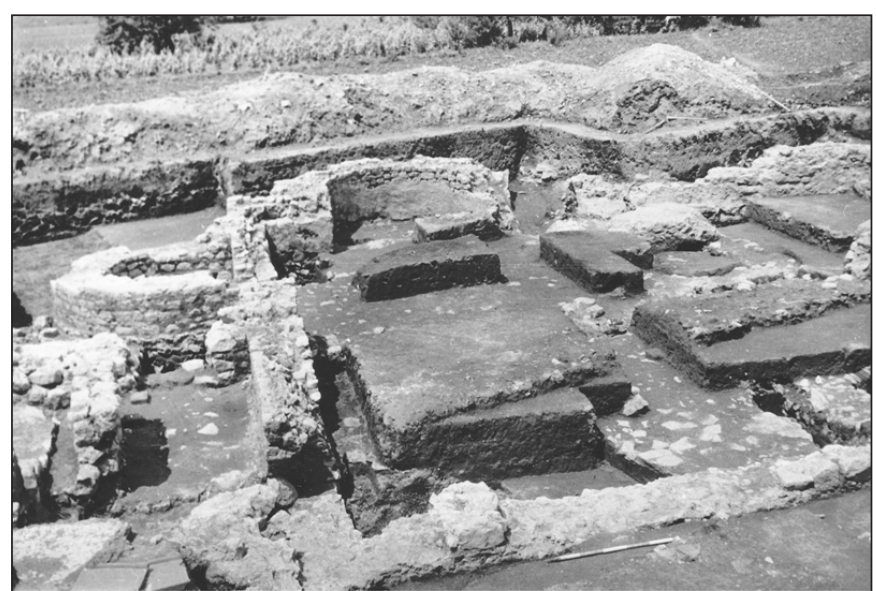
the hope of finding intact mosaics, Ferenc Fülep returned to the site in the beginning of the 1980s and found the interior of a huge hall with hypocaust heating system (Fig. 4). Its floor was once covered with fine mosaics so elaborately designed that compare to the most outstanding pieces of late Roman mosaic art. The leader of the excavation could not live to publish the results of the excavation and the sensational

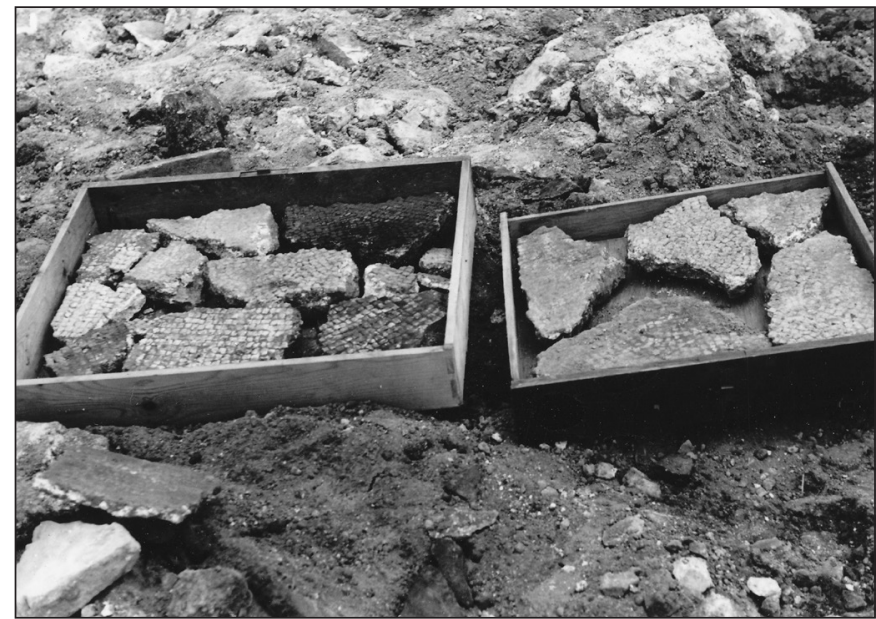

Fig. 3. Mosaic floor fragments in the furrow, broken up by deep ploughing, 1974

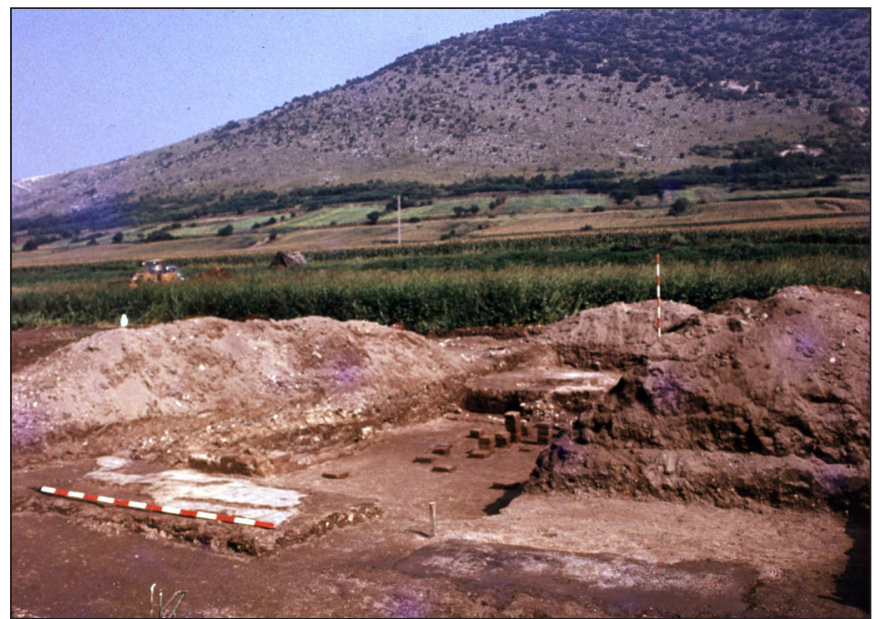

Fig. 4. The central section of the villa's banquet hall with composite heating system, excavated in 1982 
mosaic finds. Only a sketchy surface drawing remained in the incomplete documentation of the excavation. The ground plan is practically incomprehensible, because the northern and southern wall of the hall could not be localized. These unsolved problems determined the first locations and objectives of the excavations starting again in 2016.

\section{THE BANQUET HALL AND THE MOSAICS OF THE VILLA IN NAGYHARSÁNY}

We applied field survey (MrÁv, MARKó \& BRADÁK 2008, 105-110) and non-destructive geophysical surveys for detecting the settlement centre with stone buildings, partly before and partly in parallel with the excavations. Since we could not expect further results from aerial photography at the area no longer affected by cultivation (SZABÓ 2015, 102-105; SZABÓ 2020, 2014-217), we hoped that magnetic and ground-penetrating radar surveys would be effective. The latter method enabled us to detect and map the ground plan of almost the entire area of the central building complex by the autumn of $2019 .{ }^{2}$ We learnt that the nearly two football field-sized, rectangular, N-S-oriented central building complex had been constructed in several stages. A large, square inner courtyard used as a garden is situated in its centre, with smaller buildings, and perhaps a fountain. The garden was enclosed with row of pillars supporting a shady roofed portico on at least one side, and surrounded with representative side wings, bathhouses and wide corridors.

Instead of the public places of the cities, the representation of the late Roman provincial elite shifted within the walls of their own houses (SCOTT 1997, 54, 59). Private properties became the scenes of leisure time, social and cultural life, where members of the elite gathered and spent their time with intellectual activities, or with hunting and banquets. They spent a lot on the building and the interior decoration of their rural residency, since these indicated their status in social hierarchy, and reflected their wealth, erudition, and power through visual messages (ELLIS 1991, 117-127). At the same time, villas symbolized the joys of pleasant and carefree rural life, and the luxury of spare time that the income of the large estates and the abundance of nature provided to the elite (MAGUIRE 2007, 63-77). This intention is also detectable in the architectural forms and the mosaic decoration of the Nagyharsány villa, which were tools of expressing elite status in a stable and increasingly theatrical way (Sсотт 1997, 64; Sсотт 2000, 106-111). The demand for luxury is most visible on the building including the banquet hall, where the owner of the villa welcomed his peers. This building stood freely in the N-S axes of the courtyard, separately from the other buildings (Fig. 5). Its representative entrance opened in

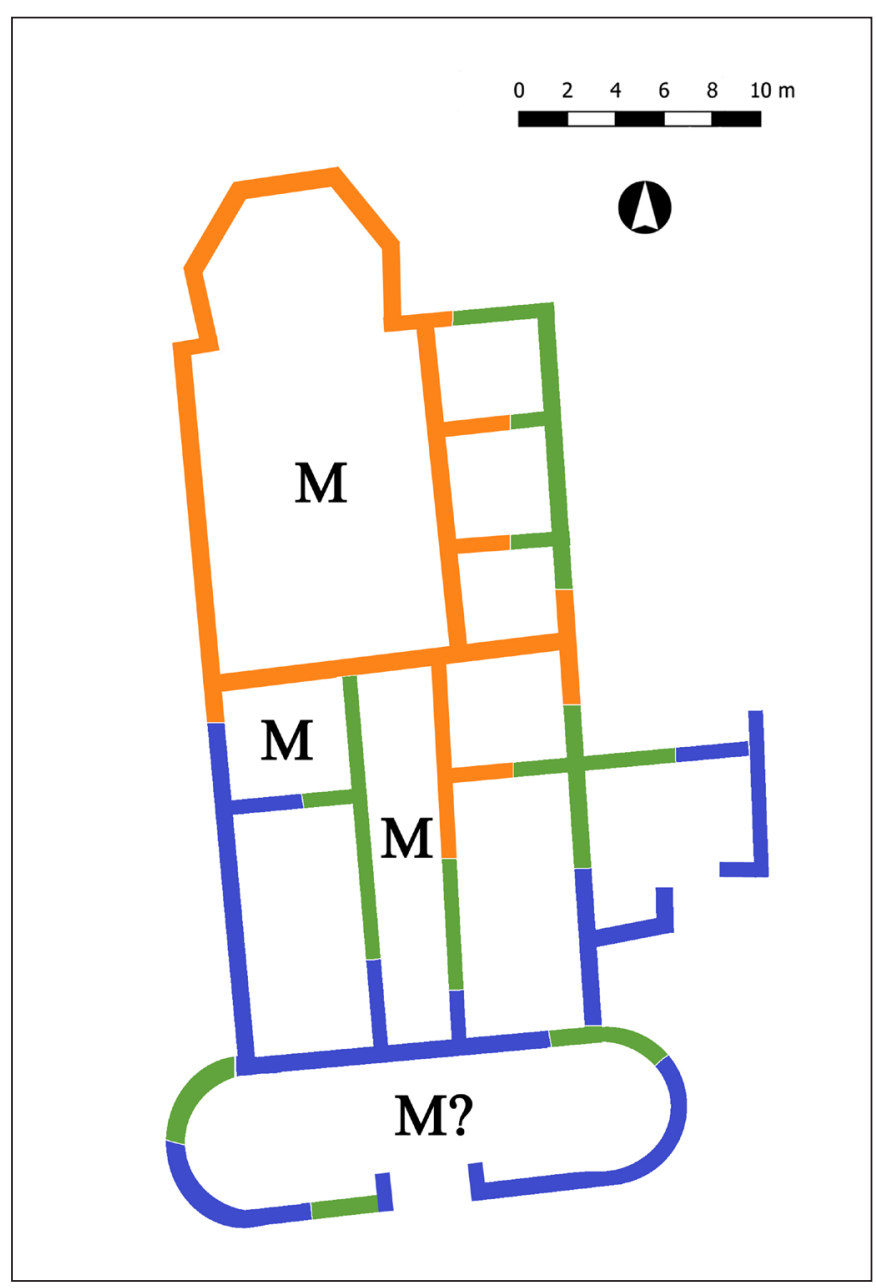

Fig. 5. The main building standing in the courtyard of the central building complex of the Nagyharsány villa. Floor plan reconstruction based on the excavations and geophysical research, a status as in 2019. Orange: walls revealed by excavation; blue: walls identified by geophysical investigations; green: supplemented walls; M: rooms with mosaic floor (reconstruction: Zsolt Mráv and Zsombor Györffy-Villám)

2 The magnetic surveys were performed by Sándor Puszta (Cossicus Ltd.) in 2017, and the ground-penetrating radar surveys by Zsombor Györffy-Villám with the devices of the Pázmány Péter Catholic University in 2018-2019. 
the middle of the southern façade, directly from the courtyard. The guests entered the vestibule with two opposite apses through an ornate, wide gate. From here, they were led through a corridor with mosaic floor and an anteroom also decorated with geometric mosaic to the banquet hall, the ground plan of which occupied nearly 180 square metres (MrÁv 2019, 19-21). The new excavations have finally enabled us to locate this hall that was not terminated with the usual semi-circular but a polygonal apsis at its northern side (Fig. 6). The feasting company was reclined here, since from here there was a good view on the main body of the hall, where they were entertained with music and dance (DuNBABIN 1996, 67-68; StePHENSON 2016, 54-71). The brick walls of the apsis were formed by five sides of the octagon, but its eastern and western walls were not parallel (Fig. 7). The hall was amended with this apsis during the last reconstruction of the building, and we are certain that it was used as a banquet hall since then at the latest. Although polygonal apses are not without an example in the Pannonian provinces, they are considered as relatively rare architectural solutions. ${ }^{3}$ On the other hand, semi-octagonal apses are frequent among villas in the area of late Roman Britannia (Cosh 2001, 236-237). Their starting point is always an extension of the hall's sidewall, therefore their width is equal. However, the apsis of Nagyharsány is narrower than the width of the hall. We can find the closest analogies of this ground plan in the Iberian Peninsula (Fig. 8). ${ }^{4}$ The numerous window-glass fragments indicate that natural light provided the primary daytime lighting of the banquet hall. The row of windows on the western wall let the light of the late afternoon and setting sun in, which created the atmosphere of the feasts reaching into the evening (ELLIs 1994, 66-68; WitTs 2000, 301, 311). Behind the windowpanes of the northern apsis wall, the sunlight outlined the silhouette of the southern, bare side of the Szársomlyó Mountain. The straight wall sections of the polygonal apses allowed more and larger windows to be inserted, therefore this type of apsis was typically

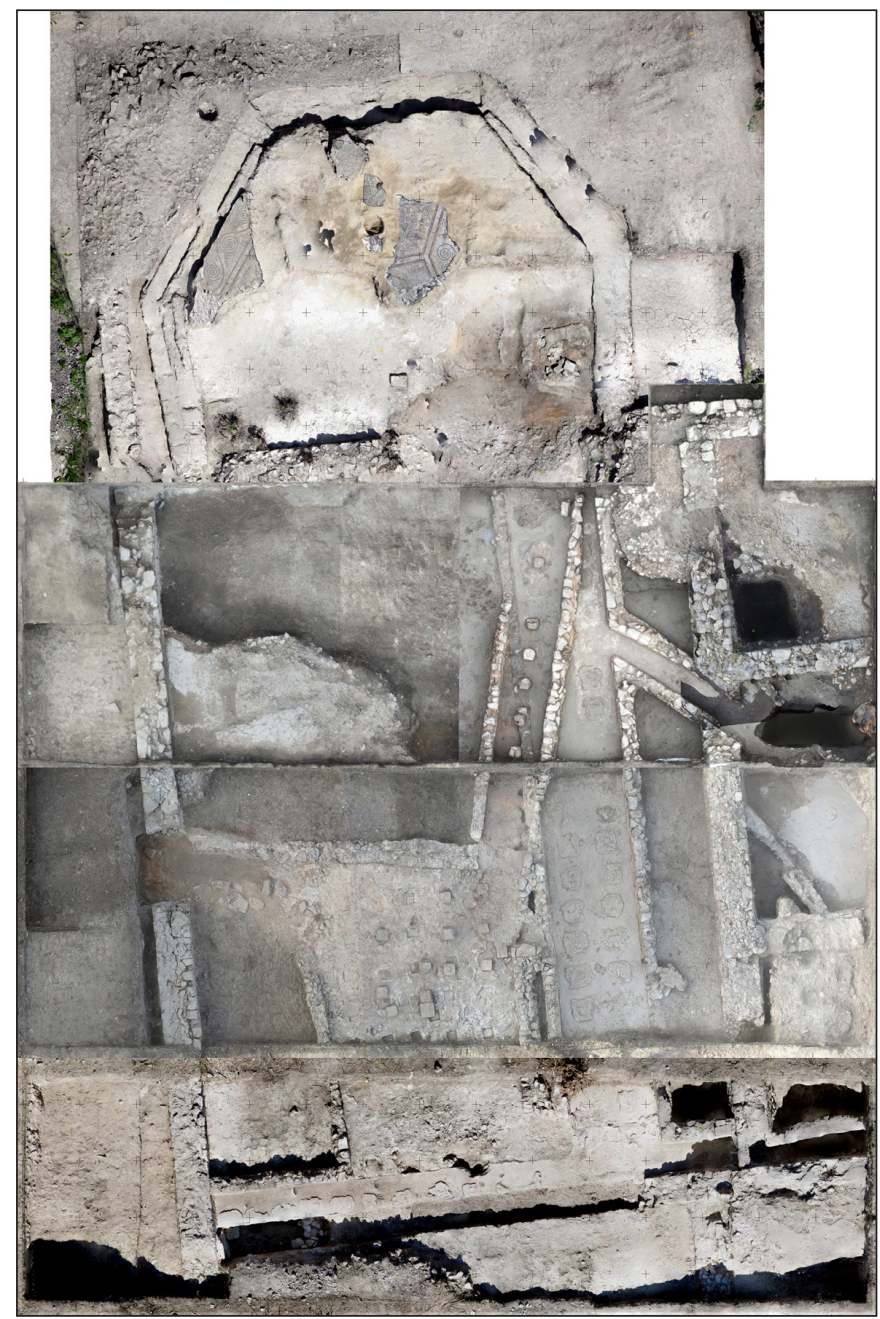

Fig. 6. The late Roman banquet hall of the Nagyharsány villa excavated between 2016 and 2019 (figure: Zsolt Mráv and Máté Szabó)

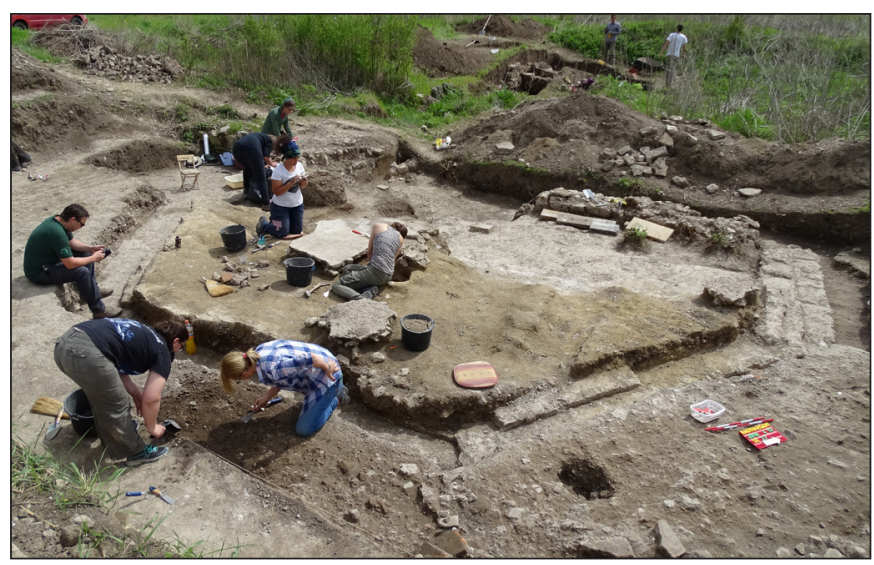

Fig. 7. The excavation of the banquet hall's polygonal apsis and its mosaic in the spring of 2018 (photo: Zsolt Mráv)

\footnotetext{
Polygonal terminating was applied in the case of the reception hall in the main building no. VII in the late Roman inner fortress at Ságvár (То́тн 2009, 34) and the external wall surface of the apsis of the 4th century, so-called hall building built above the barracks of the 2nd-3rd century legionary fortress in Aquincum (Budapest District III, Vörösvári street 1-3) (SzIRMAI \& Altmann 1976, Figs. 235 and 62).

4 For example: Aquilafuente, villa romana de Santa Lucia (Segovia); Almenara de Adaja-Puras (Valladolid); Carranque, villa de Materno (Toledo), in summary see: Chavarría Arnau 2006, 20-21.
} 
applied in the case of winter banquet halls (COSH 2001, 236 n. 60). The hall in Nagyharsány was also suitable for organizing feasts in colder seasons, since a multi-period composite hypocaust system with both channels and pillars ran under its floor. Its mosaics were most probably destroyed when the bricks of this heating system were exploited in the modern age. The mosaic fragments that preserved in the remains of the hypocaust can be estimated as less than 10 percent of the original floor surface.

The purpose of the host was to fascinate his guests with the sight of the banquet hall when they entered. The inner decoration of the banquet hall also created an atmosphere of wealth and luxury and conveyed clear messages about the owner's status and erudition. A limestone fragment with profiled frame and polished surface indicates that natural stone panels covered the inner plinth of the walls (Fig. 9). A colourful mosaic partly laid from glass tesserae covered its entire floor, its subject-matter choice implying that a sophisticated and educated person had commissioned it. Understanding the abstract allegories, identifying Greek myths, and interpreting the visual messages hidden in them demanded literacy from both the commissioner and the guests to whom this visual world was displayed. Greek mythology, and the popular themes of hunting and animal fights provided the content of the figural scenes with white background. The former is represented by a marine scene. The illusion of sea-water was evoked by rows of green glass mosaic tesserae, behind which naked female body parts are intimated (Fig. 10). The central area contains a naked female figure adjusting her

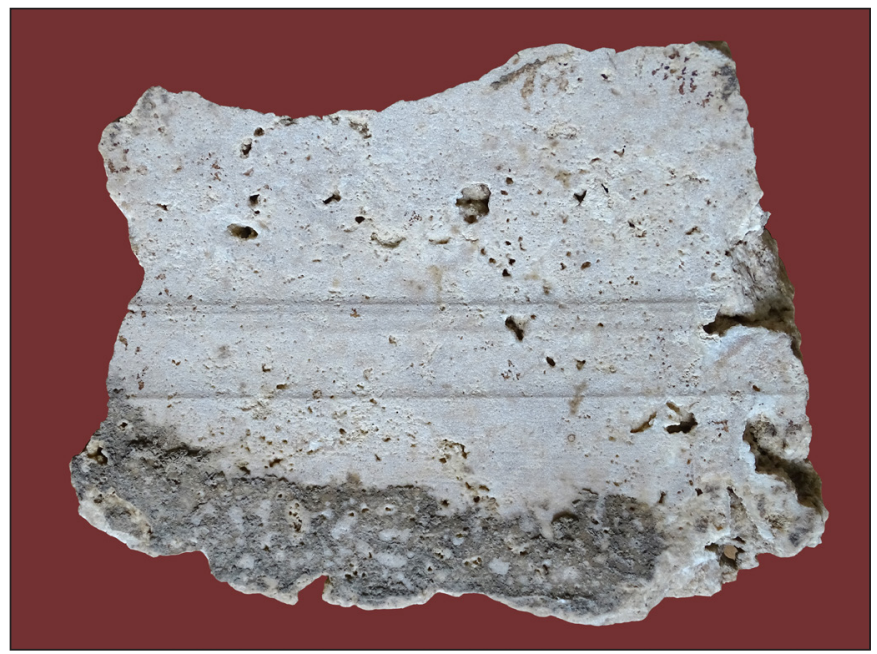

Fig. 9. Fragment of a polished limestone wall-covering panel from the banquet hall of the Nagyharsány villa

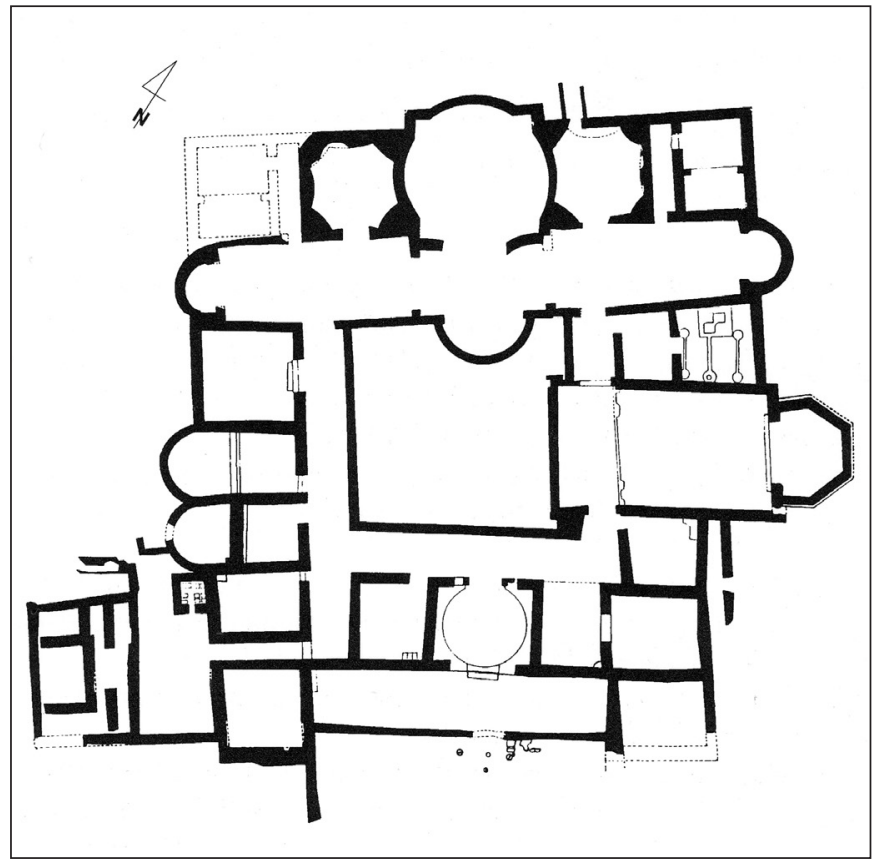

Fig. 8. Ground plan of villa de Materno in Carranque on the Iberian Peninsula and its banquet hall with polygonal apsis (after ChaVARRía ARNAU 2006, 20, Fig. 2)

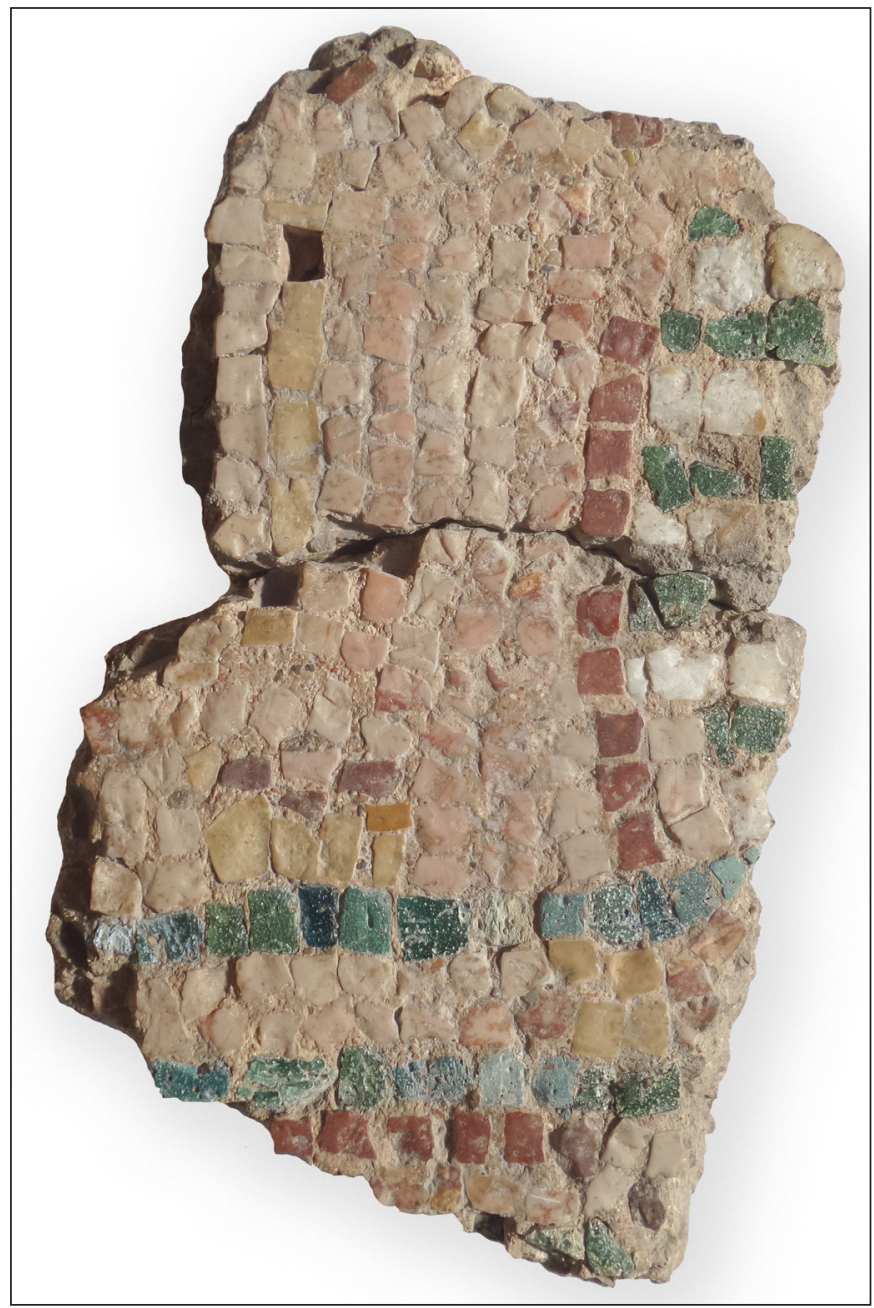

Fig. 10. A marine scene from the mosaic of the banquet hall of the Nagyharsány villa (photo: Erika Verba) 


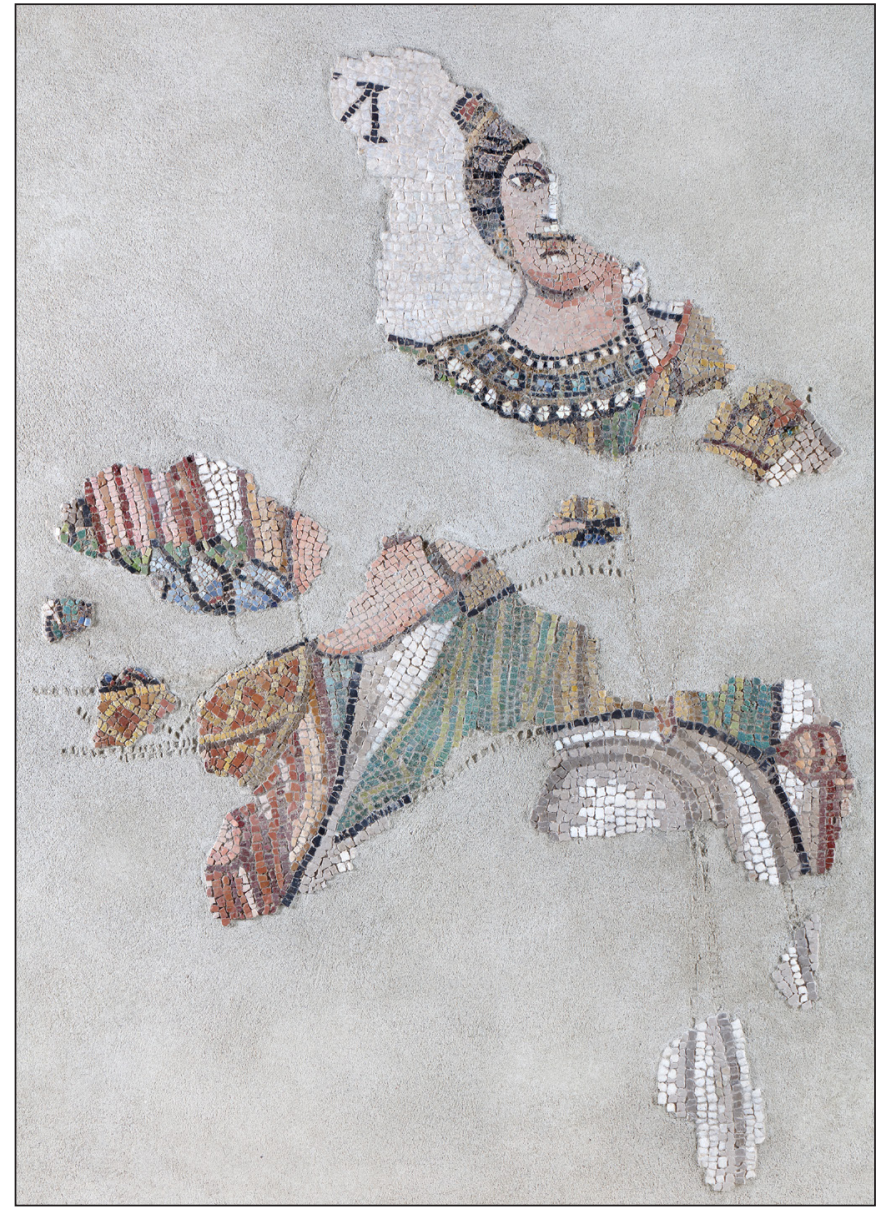

Fig. 11. A city goddess from a mosaic of the banquet hall of the Nagyharsány villa (Hungarian National Museum, photo: András Dabasi)

ures with cities by the help of the Latin inscriptions written around them. However, only a few letters remained of them, which do not allow us to complete them to a particular city name.

The apsis of the banquet hall in Nagyharsány was not heated, therefore its mosaic panel was not rummaged as much as the main body of this hall heated by a composite hypocaust system. Among others, the lower clay foundation layer beneth the apsis mosaic yielded a copper-alloy coin of Emperor Constantine the Great (AD 306-337), issued between AD 330$335,{ }^{5}$ which provides a terminus post quem for the mosaic of the apsis. The pattern of apsis mosaics in banquet halls are usually simpler that the mosaics covering the floor of the halls' main body. The reason for that may be that the semi-circular or polygonal couch (stibadium) and dining table (sigma) set up occasionally in the apsis covered a significant part of its mosaic floor (WITTS 2000, 302). The compo- hair, who can be identified as Aphrodite beautifying after being born. Another emblem depicts a heroic deed of a Greek mythological hero. So far, the hunting and animal fight scenes have revealed the figures of a deer, an onager, and a lion. The beasts were placed into a natural environment by plants formed by green glass mosaic tesserae.

The most prominent, central emblema of the mosaic floor depicted the gallery of city goddesses who recalled at least three metropolises of the Roman Empire, sitting next to each other on their thrones, and guaranteeing the eternal happiness and abundance of the Roman world order (Fig. 11). Their presence also brought fortune and prosperity to the villa owner's family and guests (Poulsen 2014, 223). The goddesses were individualized by the items held in their hands (fruit basket, cornucopia), and the different colour of their clothes (green, yellow and blue). In the absence of individual attributes, it was only possible to identify the female fig-

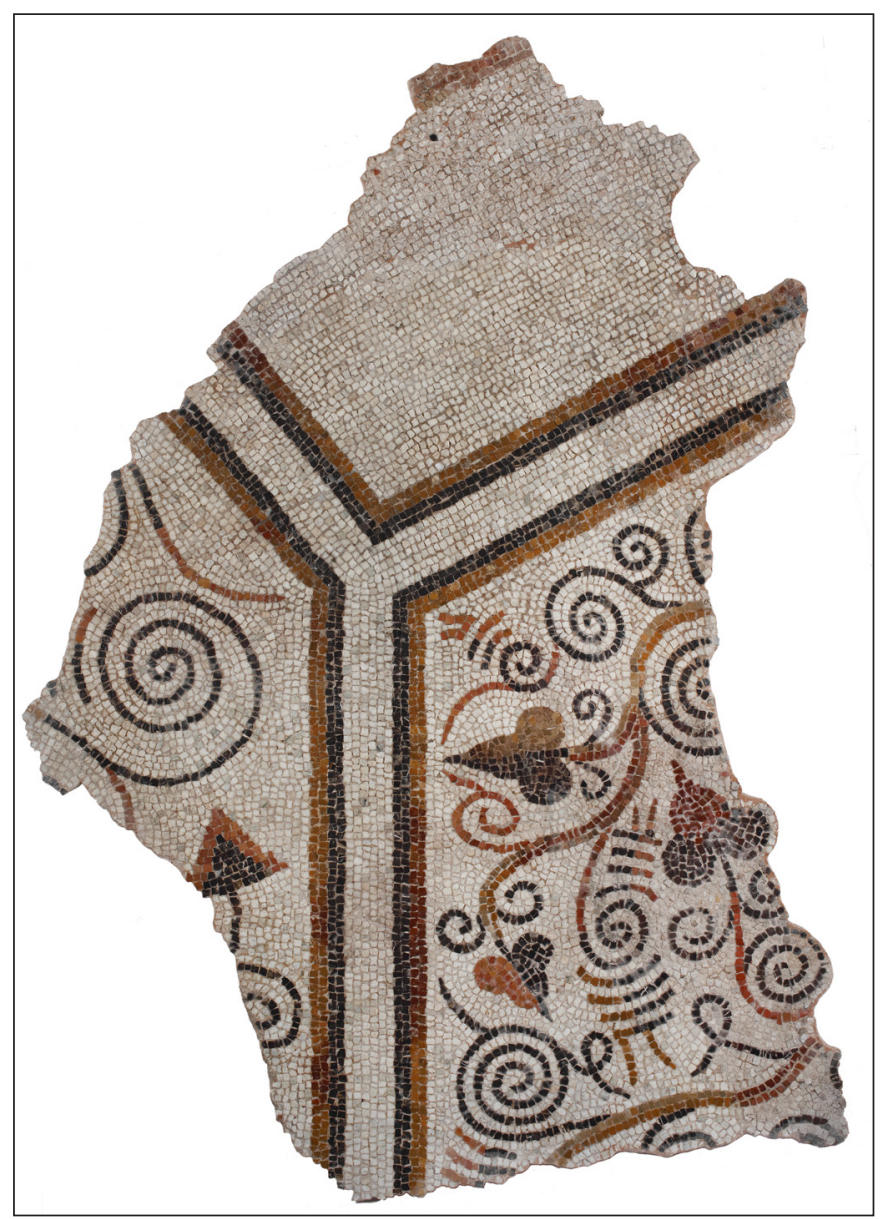

Fig. 12. A tendril motif filling trapezoidal panels on the apsis mosaic (photo: Judit Kardos) 
sition of the apsis mosaic in Nagyharsány also mirrored the shape and layout of the stibadium-couch installed above them (MorviLLEz 1996, 132-142). An elongated octagon-shaped emblema was composed in the centre of the apsis mosaic, which was surrounded by trapezoid and square fields. Each panel pictured a plant sprawling out from a vase, their weaving tendrils and leaves growing over all the available surfaces (Fig. 12). The ornament of the mosaic's framing band following the apsis wall was also built on a running tendril and the rhythmic waving of the tendril spirals growing from it (Fig. 13). This is an indirect allusion to Dionysus, in whose presence vegetation started to bloom and

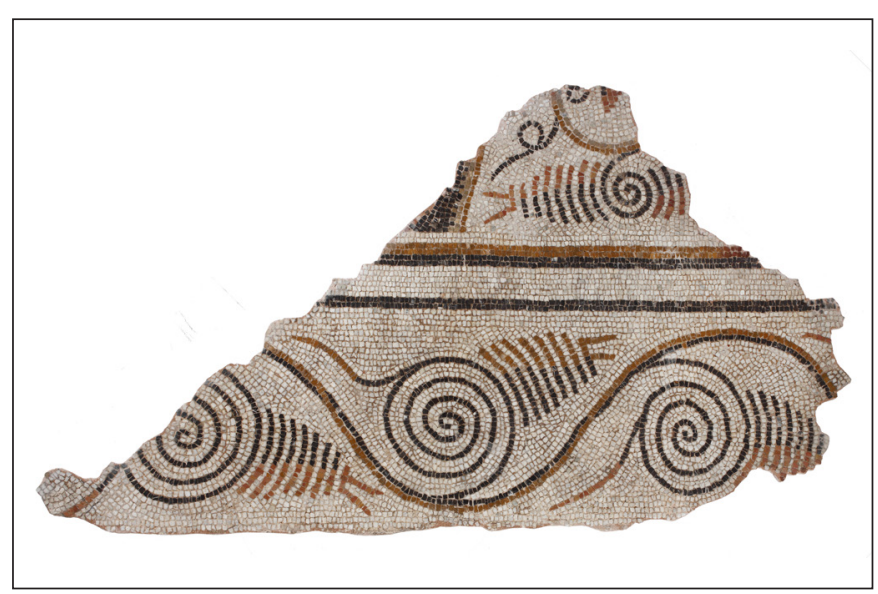

Fig. 13. The framework scroll motif of the apsis mosaic (photo: Judit Kardos) grow abundantly. The figurative representation of the emblema expressed the god's actual presence the most directly. Although only brownish red tesserae lines indicating the ground remained of it, we can be certain that it depicted the figure of Dionysus, in one of the most characteristic representation of his iconography. Besides invoking the god himself, Dionysiac imagery became the allegoric depictions of convivality, hospitality, and the happiness and pleasures of mundane life in the late imperial period (PARRISH 1995, 332).

\section{A SERVICE OF LUXURY GLASSES FROM THE VILLA}

Hundreds of tiny fragments of luxurious glass vessels came to light from the corridor in front of the banquet hall and the floor of a room opening from here. Some pieces among them represented the highest quality of late Roman glass craftmanship. Beakers and cups of late Roman wine sets were made from glass exclusively. "Gourmet" wine consumers of the late Roman period avoided the use of metal tableware deliberately, because they had experienced that their material had influenced the aroma and taste of wine negatively. Therefore, a drinking set consisting of luxury glasses was an essential part of late Roman precious metal feasting sets. The artificial evening lighting of the banquet hall was partly also provided by elaborated glass lamps (ELLIS 1994, 69-70), which contributed to the intimate and at the same time exciting atmosphere of the feasts with their play of light that illuminated their environment. Among others, the glass set from the Nagyharsány villa included cage cups and lamps, and colourful glass vessels with wheel-cut and applied gold foil overlay decoration. Some letters and semi-transparent, blue and green cage fragments and colourless fragments of the inner vessel with bridges remained of the cage cups with inscriptions (vasa

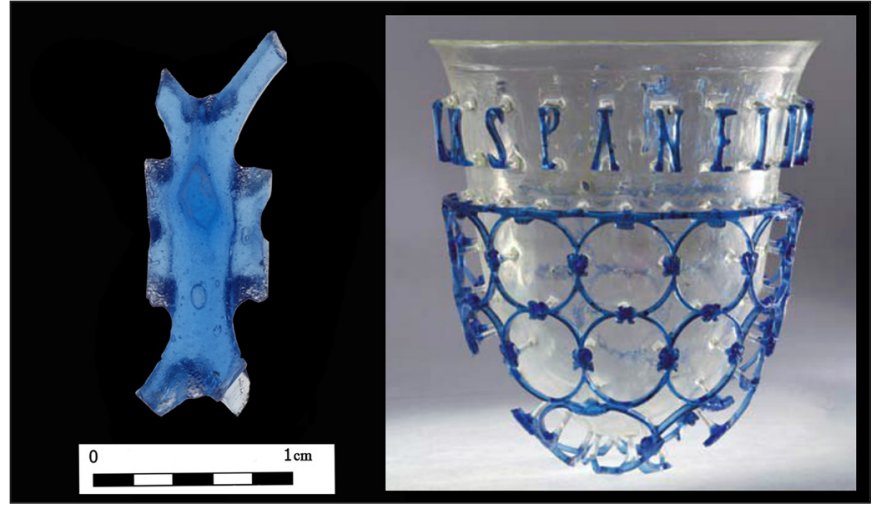

Fig. 14. Fragment of an openwork cage cup (vas diatretum) from the villa of Nagyharsány, and an intact vessel with similar blue cage from Komini, Montenegro diatreta), which indicate more than one vessels of this type. The blue cage fragments most probably belonged to a cup similar to the one found intact at Komini, Montenegro (Whitehouse 2015, 99 no. 19) (Fig. 14). The so-called dichroic glasses were real curiosities, fascinating the guests by changing their colour and transparency in front of their eyes. This transformation depended on the lighting of their environment, how light passed through them, and the fluid they were filled with. In reflected light, the glass was opaque olive green, while in transmitted light it turned to translucent orange or ruby red or purple. Today we know the light-physical background of this spectacular effect, the green and red 
dichroism, which is achieved by the refractive feature of the nanoparticles of gold and silver dispersed in the glass material (Freestone, Meeks, Sax \& Higgitt 2007, 270-277; Whitehouse 2015, 45-47). However, in late Antiquity, even educated members of the elite saw an inexplicable miracle in this light effect. Therefore, it is not a coincidence that dichroic glasses were given as precious presents and used on festive banquets (WHITEHOUSE 1989, 119-121). We know approximately ten dichroic glass fragments with accurate provenance information from the territory of the Roman Empire: among them only three originate from Italy and the western provinces (one piece each from Rome, Aquileia, and Soria in Hispania: HöPKE 2015, 295). This proves the rarity and peculiarity of dichroic glasses. So far, the excavation of the Nagyharsány villa yielded at least three dichroic glass fragments produced by various techniques, which deserves special attention from several aspects. Based on the new subtypes found here, dichroic glasses reflect a much more various picture than we had presumed on the basis of the pieces known earlier. Furthermore, the fact that more cage cups and/or dichroic glasses were used in the household of the luxury villa at Nagyharsány in the same time, and that the archaeological context of each fragments is known, is without precedent. This may lead us to the conclusion that the owner of the set was a passionate collector of rare glass specialities.

\section{THE EDUCATED AND INFLUENTIAL OWNER OF THE VILLA}

A peculiarity of the Nagyharsány villa is that we know its rich owner by name. He can be associated with the large-scale construction of the central building in the end of the 4th or the very beginning of the 5th century at the latest, as well as he may have been the patron of its mosaics. A bronze plaque came to light in the Ida

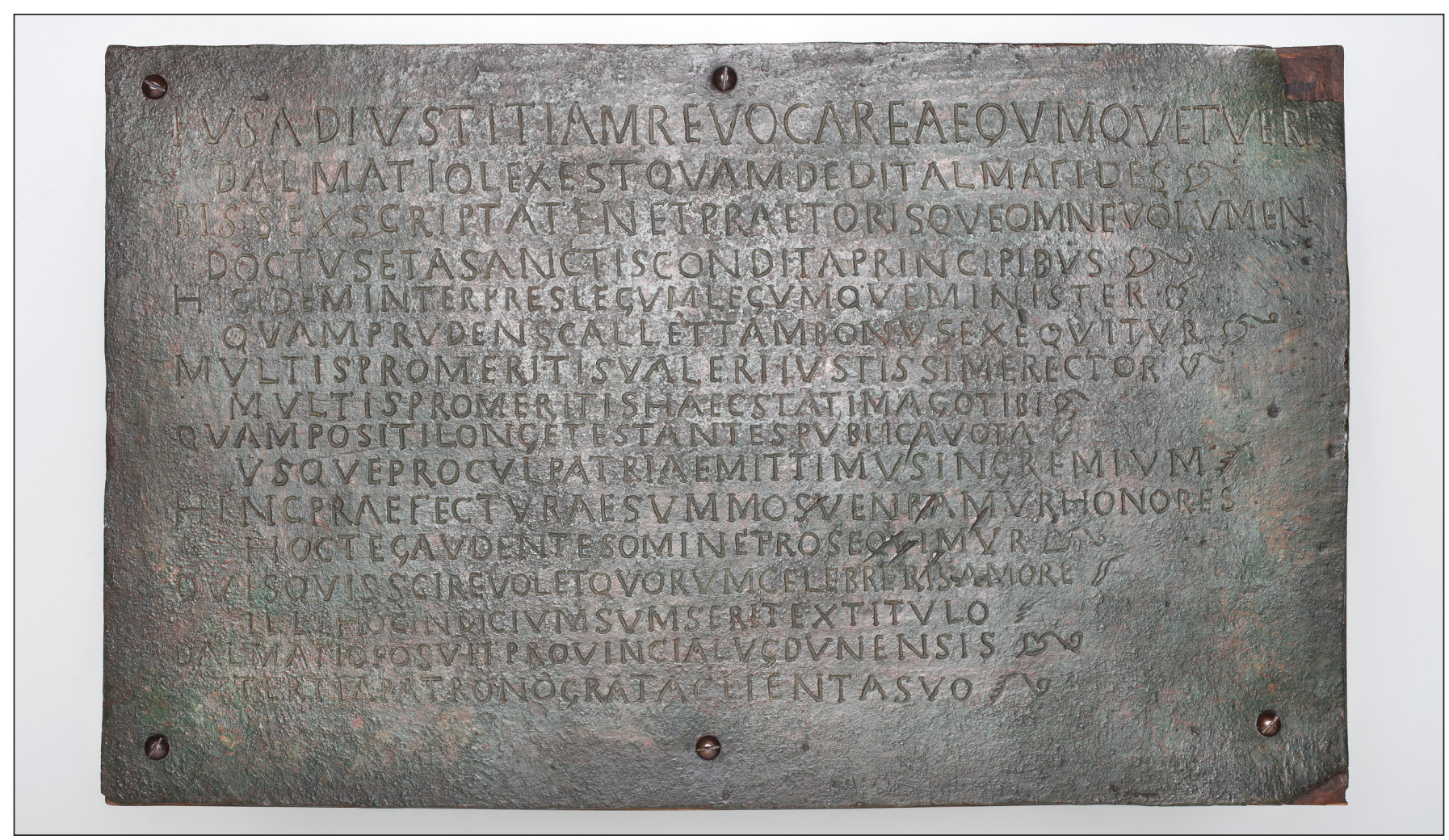

Fig. 15. The inscription from the statue base of Valerius Dalmatius from Beremend (Hungarian National Museum, photo: András Dabasi \& Judit Kardos). The verse inscription of the plaque reads: "For Dalmatius the law, which nourishing faith provides, is to restore justness to Justice and to protect even-handedness. Two times six volumes (scripta) the learned man holds, every volume of the praetor and the ones laid down by the holy emperors. The same man is interpreter of the laws and the laws' servant; he both understands them carefully and applies them well. For your many merits, Valerius, most just judge, for your many merits, this portrait stands here for you. We who have set it up bear witness to the public vows we have been making for a long time, we send it from afar into the bosom of your homeland. For this man we beseech the highest honours of the prefecture, rejoicing we pursue you with this omen. Whoever wants to know by whose love you are adored, can take the knowledge from this inscription: The province Lugdunensis Tertia set [this] up, a grateful client to her patron." (Translation: 
manor belonging to the neighbouring Beremend in 1901 (Mommsen 1902 = L'Année Epigraphique 1902, 245) (Fig. 15), which was taken to the Hungarian National Museum. The verse inscription of the plaque commemorates a senator called Valerius Dalmatius, about whom we learn to be an educated jurist and the governor of the late Roman Gallia Lugdunensis Tertia province that lays in the region of present-day Brittany, France, and Normandy in a smaller part (Prosopography of the Later Roman Empire I, Dalmatius 8; KovÁcs 2019, 38-49 [summarizing earlier literature]). He was much loved and respected in his province, since - according to the glorifying poem - his judgements aimed to harmonize law with justice. After leaving his office, the provincial council of Lugdunensis Tertia elected him as the patron of the province. Even a bust was erected in his honour, which was taken to Dalmatius' distant homeland, Pannonia, by a delegation consisting of respected citizens. The bronze plaque with inscription proclaimed the well-respected governor's virtues to his guests on the pedestal of this statue. It is worth mentioning that Savaria (Szombathely, Hungary)-born Saint Martin was the bishop of Tours (civitas Turonorum), the Lugdunensis Tertia province's capital and the governor's seat around this time (MCKINLEY 2016, 121). Although he was contemporary to Dalmatius, we do not know whether the two persons from Pannonia met personally far from their homes, and if yes, how their personalities influenced each other. If Martin was still alive, they surely met, since he was the spiritual leader of the city's Christian community, while Dalmatius represented secular power at the same place. However, if Dalmatius only became governor after Martin's death, after 397, he still had to experience the bishop's local respect and cult. Perhaps we are not far from the truth if we suppose that Saint Martin's love and popularity in Gallia had a direct role in the acknowledgement of the other Pannonian, Dalmatius.

The mosaics depicting the multiple city personifications make the direct connection between the luxury villa in Nagyharsány and senator Valerius Dalmatius certain. The residences of dignitaries of the imperial administration conveyed the messages of power even in their residential architecture and decoration, and often reflected directly on their positions and their relationship with the emperor (Sсотт 2004, 55). Even the depictions of city personifications can be associated with emperors, or influential persons who themselves were in imperial service as influential member of the administration (PoULSEN 1997, 17). In the official imagery city goddesses, especially Roma and Constantinople not only represented the entire empire, but also legitimated the high-ranking official's authority for practicing the power that comes with their position (BüHl 1995, 231; Poulsen 2014, 217-219). Thus, the owner of the Nagyharsány villa was a representative of the landowning elite linked with the Empire's power apparatus, who could not be else but Dalmatius, the governor on the inscription of Beremend. When choosing the city personifications of the mosaic, he might have considered personal aspects: metropolises were evoked where he had been in the course of his life and career, and to which he attached emotionally. However, within the walls of his own house city goddess depictions primarily propagated the elite's notion and its tradition-bound erudition. At the same time, it reminded his guests that their host was a member of the imperial aristocracy maintaining and governing the Roman Empire.

BIBLIOGRAPHY

Bühl, G. (1995). Constantinopolis und Roma. Stadtpersonifikationen der Spätantike. Zürich: Akanthus.

Chavarría Arnau, A. (2006). Villas en Hispania durante le Antigüedad tardía. In A. Chavarria, J. Arce \& G. P. Brogiolo (eds.), Villas Tardoantiguas en el Mediterráneo Occidental (pp. 17-35). Anejos de Achivo Español de Arqueología 39. Madrid: Consejo Superior de Investigaciones Científicas, Instituto de Historia.

Cosh, S. R. (2001). Seasonal dining-rooms in Romano-British houses. Britannia 32, 219-242. https://doi. org/10.2307/526957 
Zsolt Mráv •A Late Roman Luxury Villa in Nagyharsány, at the Feet of the Szársomlyó Mountain

Dunbabin, M. D. K. (1996). Convival sapces: dining and entertainment in the Roman villa. Journal of Roman Archaeology 9, 66-80. https://doi.org/10.1017/S1047759400016500

Dunbabin, M. D. (2003). The Roman Banquet. Images of Conviviality. Cambridge: Cambridge University Press.

Ellis, S. P. (1991). Power, Architecture, and Decor: How the Late Roman Aristocrat Appeared to His Guests. In E. K. Gazda (ed.), Roman Art in the Private Sphere. New Perspectives on the Architecture and Decor of the Domus, Villa, and Insula (pp. 117-134). Michigan: The University of Michigan. https://doi. org/10.3998/mpub.2429402

Ellis, S. P. (1994). Lighting in Late Roman Houses. In S. Cottam, D. Dungworth, S. Scott \& J. Taylor (eds.), TRAC 94: Proceedings of the Fourth Annual Theoretical Roman Archaeology Conference, Durham 1994 (pp. 65-71). Oxbow: Oxbow Books.

Freestone, I., Meeks, N., Sax, M. \& Higgitt. C. (2007). The lycurgus cup - A Roman nanotechnology. Gold Bulletin 40 (4), 270-277. https://doi.org/10.1007/BF03215599

Fülep, F. \& Sz. Burger, A. (1979). Baranya megye a római korban - Römerzeit im Komitat Baranya. In Bándi G. (szerk.), Baranya megye története az öskortól a honfoglalásig (pp. 221-328). Pécs: Baranya Megyei Levéltár.

Höpken, C. (2015). A dichroic bottle fragment from Dülük Baba Tepesi, Turkey. Journal of Glass Studies 57, 292-295.

Kovács, P. (2019). Valerius Dalmatius felirata Beremendről (ILS 8987) [An inscription of Valerius Dalmatius from Beremend (ILS 8987)]. Studia Epigraphica Pannonica 10, 38-49.

McKinley, A. S. (2016). Tours-i Szent Márton tiszteletének első kétszáz éve - The first two centuries of Saint Martin of Tours. Világtörténet 1, 119-145.

Mommsen, Th. (1902). Weihe-Inschrift für Valerius Dalmatius. Sitzungsberichte der Preussischen Akademie der Wissenschaften, 836-840.

Morvillez, E. (1996). Sur les installations de lits de table en sigma dans l'architecture domestique du Haut et du Bas-Empire. Pallas 44, 119-158. https://doi.org/10.3406/topoi.1997.1735

Maguire, H. (2007). The Good Life. In E. R. Hoffman (ed.), Late Antique and Medieval Art of the Mediterranean World (pp. 63-84). New York: Wiley.

Mráv, Zs. (2019). Egy késő római luxusvilla Nagyharsányban [A late Roman luxury villa in Nagyharsány]. Várak, Kastélyok, Templomok 15 (1), 18-21.

Mráv, Zs., Markó, A. \& Bradák, B. (2008). Előzetes jelentések a Magyar Nemzeti Múzeum Villány mikrorégiós kutatási programjáról - Preliminary Reports on the Micro-region Investigation "Villány and Its Region" of the Hungarian National Museum. In Kisfaludi J. (szerk.), Régészeti kutatások Magyarországon 2007 - Archaeological Investigations in Hungary 2007 (pp. 101-120). Budapest: Kulturális Örökségvédelmi Hivatal - Magyar Nemzeti Múzeum. 
Zsolt Mráv •A Late Roman Luxury Villa in Nagyharsány, at the Feet of the Szársomlyó Mountain

Parrish, D. (1995). A mythological theme in the decoration of late Roman dining rooms: Dionysos and his circle. Revue Archéologique n. s. 2, 307-332.

Poulsen, B. (1997). The City Personifications in the Late 'Roman villa' in Halikarnassos. In S. Isager \& B. Poulsen (eds.), Patron and Pavements in Late Antiquity (pp. 9-23). Halicarnassos Studies II. Odense: Odense University Press.

Poulsen, B. (2014). City Personifications in Late Antiquity. In S. Birk, T. Myrup Kristensen \& B. Poulsen (eds.), Using Images in Late Antiquity (pp. 209-227). Oxford: Oxbow.

Scott, S. (1997). The Power of Images in the Late-Roman House. In R. Laurence \& A. Wallace-Hadrill (eds), Domestic Space in the Roman World: Pompeii and Beyond (pp. 53-67). Journal of Roman Archaeology Supplementary Series 22. Portsmouth, RI: JRA.

Scott, S. (2000). Art and Society in Fourth-Century Britain. Villa Mosaics in Context. Oxford University School of Archaeology, Monograph No. 53. Oxford: Oxford University School of Archaeology.

Scott, S. (2004). Elites, Exhibitionism and the Society of the Late Roman Villa. In N. Christie (ed.), Landscapes of Change. Rural Evolutions in Late Antiquity and the Early Middle Ages (pp. 39-65). London: Routledge.

Stephenson, J. (2016). Dining as spectacle in late Roman times. Bulletin of the Institute of Classical Studies 59 (1), 54-71. https://doi.org/10.1111/j.2041-5370.2016.12019.x

Szabó, M. (2015). Baranyai villák légifelvételeken [Villas in Baranya County on aerial photos]. Janus Pannonius Múzeum Évkönyve 53, 87-114.

Szabó, M. (2020). Római kori villagazdaságok légirégészeti kutatása Magyarországon [Aerial archaeology of Roman period villas in Hungary]. Archaeológiai Értesitö 145, 207-235. https://doi. org/10.1556/0208.2020.00011

Szirmai, K. \& Altmann, J. (1976). Előzetes jelentés a ferencesek temploma és a via praetoriától északra húzódó római kori épületmaradványok régészeti kutatásáról [Preliminary report on the research of Roman period buidings north of the Franciscan church and the via praetoria]. Budapest Régiségei 24 (1), 233-244.

Tóth, E. (2009). Studia Valeriana. Az alsóhetényi és a ságvári késő római erödök kutatásának eredményei [Studia Valeriana. Research on the late Roman forts in Alsóhetény and Ságvár]. Dombóvár: Dombóvári Városszépítő és Városvédő Egyesület.

Whitehouse, D. (1989). Roman dichroic glass: Two contemporary descriptions? Journal of Glass Studies 31, 119-121.

Whitehouse, D. (2015). Cage Cups. Late Roman Luxury Glasses. New York: The Corning Museum of Glasses. https://doi.org/10.3764/ajaonline1231.jones

Witts, P. (2000). Mosaics and room function: The evidence from some fourth-century Romano-British villas. Britannia 31, 291-324. https://doi.org/10.2307/526924 